\title{
Cousin marriage, hierarchy, and heredity: contestations over domestic and national body politics in 19th-century America
}

\author{
Radcliffe-Brown Lecture in Social Anthropology \\ read 4 October 2018
}

\section{SUSAN McKINNON}

Abstract: How did cousin marriage - an institution that had been not only common, but also emotionally resonant, culturally validated, and economically productive in America - come to be recast as emotionally repugnant, medically dangerous, and politically backward? This paper follows 19th-century opponents of cousin marriage who framed their argument by positing a concordance between marital types (inversus out-marriage) and political types (monarchical versus republican). In the language of humoral medicine, these arguments recalibrated the previously positive associations between cousin marriage and hierarchical systems of hereditary rank by linking it to ideas about ill health and the degeneration and decline of family lines and European monarchies. Simultaneously, the negative evaluation of marital mixing across ranks and between populations was dismantled by correlating out-marriage with the egalitarian ideals of republicanism and connecting it with the positive values of health, vitality, and progress - of individuals, family lines, and the new American republic - a connection that was, however, contradicted by the racial politics of antebellum America.

Keywords: Kinship, cousin marriage, hierarchy, heredity, humoral medicine, aristocracy, monarchy, republicanism.

\section{RADCLIFFE-BROWN AND LÉVI-STRAUSS, COUSIN MARRIAGE, AND BEYOND}

With this essay on cousin marriage, I wish to pay my respects to two ancestors. First, of course, Alfred Reginald Radcliffe-Brown, whose analysis of Australian section systems (1930-31: 131-74) is, quite simply, stunningly brilliant. There are, perhaps, no 
more exquisitely complex systems of marriage in the world than these; and comprehending them was a challenge that he seemed to meet with ease, while many of us struggle on in vain. I also wish to honor Claude Lévi-Strauss, whose Elementary Structures of Kinship (1969) is a dazzling analysis of the distinctive structural implications of different forms of cousin marriage. The two masters did not always agreefor instance, on what Lévi-Strauss (1963: 31-54) called, with a twinge of physics envy, the 'atom of kinship'. But they both explored - as I will also do in this essay - the structural power of different forms of marriage to express distinctive forms of social organisation.

Also at the centre of this essay is a question asked by Lévi-Strauss (1985: 73) late in his career: why cultures, which 'recommend or prescribe marriage between cousins ... at some point in their history, ... [have been] induced by circumstances to give up one marriage form for another'. Examining the motives of the characters in the 11th-century novel, The Tale of Genji, his answer was, perhaps, very French, but also rather unconvincing: 'marriage to a near relative', he said (1985: 74), 'is not usually held to be very interesting ... there is no mystery, no excitement'. Although LéviStrauss did not delve more deeply to consider why this change in sentiments took place - or, indeed, why more distant cousins should be more exciting than those nearer-he nevertheless extrapolated from this evaluation a more general contrast that tied different forms of marriage to broader narratives of modernisation. Close kin marriage, he suggested, is both more secure and more static, it simply repeats and reproduces rather than transforms; while marriage with more distant kin - and, presumably, also with non-kin - is both riskier and more dynamic and it is an opening to historical transformation (Lévi-Strauss 1985: 74). ${ }^{1}$

This contrast does not really bring us any closer to understanding either the historical dynamism of cousin marriage at specific moments in time or to the cultural meanings that might have motivated people in a certain historical context to give up cousin marriage. It is precisely this latter question that I wish to address in this essay. What motivated Americans - at a particular moment in their history - to give up, stigmatise, and at least partially prohibit a form of marriage that had hitherto been

\footnotetext{
${ }^{1}$ This is a version of Lévi-Strauss's (1969: xxxiii-xxxix) earlier distinction between what he called the elementary and complex structures of kinship. The former were characterised by alliances between groups, by the positive determination of the preferred spouse (such as a man's mother's brother's daughter or father's sister's daughter), and by the operation of a system of ceremonial gift exchange; while the latter were distinguished by the 'freedom to choose the spouse within the limit of prohibited degrees; equality of the sexes in the matter of marriage vows; and ... emancipation from relatives and the individualization of the contract' (Lévi-Strauss 1969: 477).
} 
emotionally resonant, legal, commonplace, culturally validated, and economically dynamic and productive?

Theoretically, this essay addresses a number of issues. First, this is a story about the intimate relationship between kinship and politics - specifically one that tells us something about the ability of different forms of kinship and marriage to articulate distinctive, contrasting forms of political organisation (McKinnon 2013, McKinnon \& Cannell 2013). Second, this is a story about radical social change - about the historical transformation from a hierarchical system of social and political relations to one with egalitarian aspirations. What does it take to dismantle an embodied set of social distinctions and engender a new one? Third, this is a story that is relevant to the history of science and medicine - concerning the peculiarity of mid-19th-century medical understandings of health, disease, and heredity and the ways in which these understandings were engaged to denaturalise an embodied logic of social hierarchy. And, finally, this is a story that gives us a glimpse into the historical formation of one of the core themes in contemporary narratives of modernity, one that links non-kin monogamous marriage with democratic political formations, and both with the idea of social progress.

The temporal period that is the focus of this essay stretches roughly from 1700 to 1900 and my argument unfolds in five sections. In the first section, I look at existing demographic and economic arguments for the decline of cousin marriage. While these arguments are not trivial, in the second section I want to set my own argument against the larger background of the radical social and political transformations that were occurring in a wave of revolutions in the Americas and Europe during this period. If the hierarchical political order of European aristocratic and monarchical societies was to be truly dismantled in America-if, as Thomas Paine (1776: 34) proclaimed in Common Sense, the crown was to be 'demolished and scattered among the people'how were Americans to reshape ideas about both marriage and heredity to fit the contours of their new republican order? In order to answer this question, over the subsequent three sections I follow the opponents of cousin marriage as they formulated their argument in terms of a set of conceptual relations in which political, medical, and hereditary understandings were tightly intertwined. I explore how these arguments dismantled the previously positive associations of cousin marriage by linking it with the negative values of ill health and the degeneration, decay, and decline of family lines and aristocratic polities. I then pause to understand the medical logic of humours and temperaments that guided 19th-century understandings of health, disease, and heredity. And, finally, I investigate the other side of the equation: that is, the way in which the negative associations of mixing ranks and populations were undone by connecting out-marriage with the positive values of health, vitality, and progress - of individuals, family lines, and democratic republics; and I consider the 
limitations of the argument for out-marriage in the context of the racial politics of antebellum America.

\section{THE DEMOGRAPHIC AND ECONOMIC ARGUMENTS}

The demographic argument about the demise of cousin marriage is pretty straightforward. Between 1800 and 1900, the fertility rate for 'white' women in the United States was cut in half, falling from seven to eight live births over a lifetime to three or four (Haines n.d.; see Kuper 2009: 252-53 for a similar demographic decline in Britain). Simply put, there were far fewer cousins in the marriage pool by the end of the 19th century, and therefore far fewer cousin marriages were even possible.

The economic argument is more complex. In America - as in Europe, according to David Warren Sabean and Simon Teuscher (2007: 1-32) - there seems to have been a rise in cousin marriage between the years 1700 and 1900. In addition to a generally positive valuation of marriages between kin, there were several economic factors that contributed to the flourishing of cousin marriage ${ }^{2}$ and sibling-set marriage ${ }^{3}$ in America during this period. Historians Peter Dobkin Hall, Betty Farrell, and others argue that cousin marriage and sibling-set marriage, taken together, provided a means for addressing the capital needs that fuelled economic expansion in America in three critically linked economic arenas: in the expanding global trade-particularly in the post-revolutionary era, after American merchants were freed from British trading restrictions (Hall 1977, 1978); in the emergence of the industrial revolution in textile production around Boston in the early 19th century (Hall 1977, 1978, Farrell 1993); and - intimately linked to the textile industry-in the expansion of plantation production of cotton in the slave economy of the South (Baptist 2014).

Why were cousin marriage and sibling-set marriage essential in all this? Hall notes two reasons. First, the marriage of cousins and of sibling sets - out of all other marriage possibilities - had a potent effect in concentrating wealth in land, labour, and/or capital precisely because it could counter the dispersive effects of American partible inheritance laws through the reduction of the number of divisions of inheritance in

\footnotetext{
${ }^{2}$ For sources on cousins and cousin marriage in 18th- and 19th-century America, see, among others: Arner (1908), Brown (1951), Cashin (1990), Censer (1984), Faber (1972), Farrell (1993), Gough (1989), Griffen \& Griffen (1977), Hall (1977, 1978), Kulikoff (1976, 1986), Ottenheimer (1996), Reid (1988), Smith (1980), Supple (1997), Vernon (1979), Wiencek (1999), Wright (1889), and Wyatt-Brown (1982).

${ }^{3}$ Sibling-set marriage refers to cases in which two brothers in one family marry two sisters in another, or a brother and sister in one family marry a sister and brother in another. Sibling-set marriages were often used in conjunction with cousin marriages within the same or succeeding generations-resulting in families that were tightly woven together over multiple generations.
} 
the next generation (Hall 1977: 42-3; 1978: 102-3). Second, Hall (1978: 105) argues, prior to the secure establishment of a host of financial institutions and legal instruments over the late 18 th and early 19 th centuries, ${ }^{4}$ capital expansion was possible only through the formation of partnerships, 'in which business capital is identical with the personal funds of the partners'. Because these partnerships tended to be formed with kin — related through blood and marriage — cousin and sibling-set marriages provided the key means of raising capital and concentrating wealth for economic expansion (Hall 1977: 43).

Hence a central paradox of cousin marriage during the revolutionary and postrevolutionary era: the very reason that cousin marriage was economically productive during this period - its ability to concentrate and magnify wealth effectively —also put it at odds with the emerging egalitarian ethos of the revolutionary era. Although cousin marriage was practised across classes in America, its social consequences were most evident as it helped to bring into being an upper-class elite that had all the trappings of an aristocracy.

All this points to a clear economic rationale for not only the rise but also the waning of both cousin and sibling-set marriages between the years 1700 and 1900 . With the development of a wide array of financial institutions and legal instruments that could provide and shelter large pools of capital, cousin and sibling-set marriages, Hall (1978: 105) contends, were no longer the most effective way of pooling capital.

The decline in the fertility rate and the rise of new financial and legal structures provide two good reasons for the waning of cousin marriage in the America - and in Britain, as Adam Kuper (2009: 251) has also pointed out in his book, Incest and Influence: The Private Life of Bourgeois England. But they do not account, I would argue, for the intense stigmatisation and prohibition of cousin marriage in the United States. There is nothing about cousin marriage that is inherently counter to an industrial economy in the 'modern' world, as evidenced by its continued legality throughout most of the world. ${ }^{5}$ The question therefore remains: how and why, over the course of the 19th century did cousin marriage begin to be transformed in the United States from a cherished institution into one seen as emotionally repugnant, medically dangerous, and politically backward.

\footnotetext{
${ }^{4}$ These financial institutions and legal instruments included banks, savings and loans, insurance companies, the stock market (founded in 1792), corporate structures, and forms of testamentary trusts that permit 'a circumvention of strict partible inheritance while satisfying traditional mandates of sharing family fortunes' (Hall 1978: 105; see also Hall 1977: 47).

${ }^{5}$ See Ottenheimer (1996) for laws relating to cousin marriage in the United States and Europe; and Bittles and Black (2015) and other resources on consang.net (http://consang.net/index.php/Main_Pagel) for maps and global patterns of consanguineous marriages. See also Wikipedia (https://en.wikipedia.org/ wiki/Cousin_marriage), for maps and a detailed account of which nations and religions permit or prohibit cousin marriage.
} 


\section{THE REVOLUTIONARY CONTEXT}

Going beyond the economic argument, I want to set my analysis about the demise of cousin marriage in the context of the American Revolution and its challenge to the hierarchical order that had been the foundation of 17th- and 18th-century social life in Britain and America, alike. Americans were certainly not the first to challenge the dominant hierarchical order either philosophically or politically. ${ }^{6}$ However, what I want to follow in this essay is the peculiarly American version of this challenge in the late 18 th and 19 th centuries.

Because Americans presupposed a concordance between the values that organised what they called the big and little commonwealths (Yazawa 1985) - the political and domestic domains - the American Revolution entailed a radical change not only in political relations, but also in relations of marriage, inheritance, and heredity. There are two aspects of the relation between the big and little commonwealths that are relevant to our story here.

First, the structure of social and political relations - and what were called the 'ligaments of affection' (Yazawa 1985: 9-18) that knit them together-was expressed in kinship terms that shifted, in the process of the revolution, from a vertical, hierarchical model to a horizontal, egalitarian one. As is well known, in the patriarchal model, a common hierarchical thread was woven through analogous sets of relations-between god and man, ruler and ruled, husband and wife, father and child, motherland and colonial progeny - and through the 'ligaments of affection' - the mutual, if highly differentiated, responsibilities - that tied superior and inferior together (Filmer 1680, Yazawa 1985).

As Americans sought to break away from their tyrannical parent and to dissolve the hierarchical patriarchal bonds that had held together the British-American imperial family, they did not abandon the key idea of the concordance between the big and little commonwealths. But the revolutionaries began to imagine the 'union' of the thirteen colonies - and their 'ligaments of affection'-in terms of more horizontal, lateral bonds of friendship, siblingship, and - in what I wish to focus on here in this essay - marriage. ${ }^{7}$ They envisioned a political union that, like the marital union, should be

\footnotetext{
${ }^{6}$ Most notably, John Locke's Two Treatises of Government (1698) was an explicit refutation of Robert Filmer's stark defence of the patriarchal model and the absolute power of fathers and kings in his Patriarcha: The Naturall Power of Kinges Defended against the Unnatural Liberty of the People (1680). In his 'Introduction' to Locke's Two Treatises, Peter Laslett (1988) situates these works in the context of 17 th-century political revolutions in Britain.

${ }^{7}$ One could argue that the overarching trope for egalitarian relations in marital as well as political and economic relations was 'friendship'. I am grateful to Caroline Arni for pointing me to a number of authors who have discussed feminist ideals - primarily from the 17th through the 19th centuries - of egalitarian marriage and politics imagined in terms of friendship. See, for instance, Shanley (1991), Abby
} 
secured through the affections of voluntaristic consent, mutual love, friendship, and symmetric responsibilities, not through the natural, unbreakable asymmetric affections defined by patriarchal power. ${ }^{8}$

At the core of the hierarchical and aristocratic political order that the Americans sought to overturn was a second aspect of the entanglements of the big and little commonwealths I want to examine: that is, the structure of natural and divinely ordained differences in rank that were articulated through particular ideas and practices about marriage, inheritance, and heredity. The continuity of the hierarchical and hereditary distinctions of the aristocratic class depended upon the 'in-and-in' marriage of people of the same rank and even family_-'like' reproducing 'like'. As Philip Wilson (2007: 142) observes, 'Hereditary aristocracy had long been based on the idea that the essence of nobility was transmissible. Retaining this essence, so the nobility customarily believed, required a purity of bloodlines without any interference through interclass marriage.' And it also required the narrowing of inheritance lines through the practice of primogeniture, which secured and concentrated landed wealth in the senior descent line.

The problem for revolutionary and post-revolutionary Americans, then, was how to dismantle this embodied logic of what was perceived as a natural and divinely ordained social hierarchy. The anti-aristocratic bent of American republicanism was realised domestically - in the 'little commonwealth' - by etching a sharp contrast between American and British forms of inheritance and marriage. Americans explicitly favoured the equalising effects of partible inheritance over British laws of primogeniture. As Alexis de Tocqueville wrote in Democracy in America (1835 vol. 1: 52), the democratising consequences of partible inheritance had been dramatic - 'striking at the root of landed property', and thus of aristocracy, 'and dispersing rapidly both families and fortunes'. They were also realised through the values of what came to be called in the years after the revolution, 'republican matrimonialism' (Fliegelman 1982: 295), which stood as a rebuke to the values that Americans presumed guided the aristocratic marital logic of British and other European societies. ${ }^{9}$ A felicitous term, it

(1999), Arni (2006), and Frazer (2008). For friendship in Scottish Enlightenment ideas about commercial society, see Hill and McCarthy (1999); and for friendship (and neighbouring) in American revolutionary thinking, see Smith (2010). And for an illuminating historical account of shifting relations between the concepts of friendship and kinship in Britain from the 17th through the 19th centuries, see Strathern (in press).

${ }^{8}$ I discuss this transformation in more detail in McKinnon (n.d.), where I draw heavily on the work of a number of American historians, including Jordan (1973), Fliegelman (1982), Shanley (1982), Shanley \& Stillman (1982), Lewis (1987), Yazawa (1985), and Basch (1995).

${ }^{9}$ It perhaps goes without saying that American understandings were not the result of a sociological study of actual British marital patterns, but rather served as a foil against which it was possible to signify the revolutionary distinctiveness of American social and political relations. 
captures the essential merging of marital and political meanings. As Jan Lewis (1987: 689) tells us, 'Marriage was the very pattern from which the cloth of republican society was to be cut.'

During the revolutionary and post-revolutionary era - in novels, advice books, and magazine articles-Americans were schooled in what kind of partners to seek, and which ones to avoid. Both men and women were strenuously warned to stay clear of particular types: 'Those associated with the despicable aspects of European court life: flatterers, deceivers, flirts, fops, coxcombs, coquettes, and all persons lacking in honor and virtue' - figures that, Lewis (1987: 697-8) maintains, promised 'ruin not only for themselves and their victims but also for the infant nation'. Individual merit, love, and friendship should be the guide, not the consolidation of hereditary rank and wealth; and modest advancement rather than ostentatious luxury should be the goal (Lewis 1987: 696).

It was not only in the popular press that a concordance between the marital union and the political union became significant. In directly connecting types of marriage and types of polities - the little and big commonwealths of affection - colonial and revolutionary Americans followed, among others, the work of Montesquieu, who, in both the Persian Letters (1728) and The Spirit of the Law (1748), drew a strong contrast, for instance, between polygamous domestic arrangements, despotism, tyranny, and theocracy, on the one hand, and monogamy, liberty, and republican government, on the other (Montesquieu 1748: 22-7, 43-50, 55-8, 270, Shanley \& Stillman 1982, Cott 2000: 10, 22, 114-15, 161). Thomas Paine, whose 1776 pamphlet, Common Sense, was successful in exhorting Americans to revolt against the tyranny of King George III and the British Parliament (Winthrop 1973), also focussed attention on the trope of the marital union (Fliegelman 1982: 123-5, Lewis 1987: 692, Basch 1995: 230-1, McKinnon n.d.). In the year and a half between January 1775 and July 1776 (the month in which the Declaration of Independence was issued), Paine served as the editor of the short-lived Pennsylvania Magazine; or American Monthly Magazine. During this time, when he also must have been busy writing Common Sense-Paine $(1775 \mathrm{a}, 1775 \mathrm{~b})$ found time to write, under pseudonyms, several pieces on marriage for the magazine and he included the work of others who were similarly concerned with the nature and significance of marital unions. Paine's articles make evident that the ideals of life, liberty, and the pursuit of happiness shaped marital as much as political aspirations of those rebelling against the old order.

It is in this context that cousin marriage's association with European aristocracies and monarchies - as well as with American efforts to consolidate elite - indeed aristocratic - class position and wealth began to become suspect. This was, I would suggest, particularly the case once the economic productivity of cousin marriage began to decline in the mid-19th century. 


\section{THE ARGUMENTS AGAINST COUSIN MARRIAGE}

Indeed by the mid to late 19th century, the contradictions between a number of hierarchical 'domestic' institutions and the promises of the revolution became too odious to bear and, as a consequence, efforts to oppose and prohibit these institutions strengthened over the course of the century. This was, of course, most obvious in the fight against slavery in the abolitionist movement and the Civil War. But it was also evident in the strenuous popular and governmental opposition to Mormon polygamy and theocratic governance in the Utah territory (Lieber 1855, Gordon 2002, McKinnon 2019 , n.d.), as well as in the emergence of arguments against the hierarchical implications of cousin marriage.

In tune with the wave of anti-monarchical revolutions in Europe in the first half of the 19th century, Americans constructed an intellectual case for the association between cousin marriage, the degeneracy and decline of in-marrying royal and aristocratic family lines, and the demise of ancient and contemporary monarchical and aristocratic political orders. In these accounts what stands out is not only the intimate association that authors made between a marital and political type - cousin marriage and monarchy - but also the way they recalibrated the cultural evaluation of these linked types through medical ideas about disease and heredity to paint a negative picture of hereditary degeneracy and political decline.

For instance, in his 1869 article, 'The Intermarriage of Relations', Dr Nathan Allen provided an encyclopedic review of the contemporary literature on consanguineous marriages. In considering the consequences of royal marriages across history and diverse cultures, Allen (1869: 246-7) asserted:

In the history of the royal founders of different nations there has been at times a great number of such intermarriages, and it is well known that very many of these have proved decidedly unfavorable as far as offspring is concerned. ... The power and influence which these families had endeavored in this way to perpetuate had come to naught, and their names in history almost extinct.

American commentators reserved special contempt for contemporary European royalty. Dr Charles Caldwell (1836: 21; see also 1834: 31-2), of Kentucky, drew a direct link between cousin marriage and the degeneration of royal families in Europe:

Be the cause what it may, both history and observation testify to the fact, that the issue of marriages between parties related by consanguinity always degenerate. They become enfeebled in time, both mentally and corporeally. This practice, which is fostered chiefly by the false pride of rank, has reduced almost to dwarfishness the nobility of several nations, especially of Portugal. It has likewise aided not a little in not only deteriorating, but nearly extinguishing, most of the royal families of Europe. 
Dr Caldwell (1836: 21) considered this 'fact' of degeneracy through 'in-and-in' marriage especially notable given his understanding that 'the ancestors of these families were the real proceres or natural nobles of the land; men particularly distinguished in their day as well for corporeal stature, strength, and comeliness, as for mental excellence.' While Caldwell focussed attention on the nobility of Portugal, F. E. H. Steger, of Maysville, Alabama, expressed his complete distain for the contemporary Spanish monarchy. In the March 1855 edition of the Nashville Journal of Medicine and Surgery, Steger (1855: 191) declared: 'From the time of Charles 5th', the Spanish monarchs 'selected wives, often near relatives, from considerations of mere personal aggrandisement ... and the consequence has been that the race is, as it ought to be, nearly extinct, exhibiting to the world a beautiful specimen of a queen in the person of the present lecherous fugitive!' Steger was presumably referring to Queen Isabella II, who married her double first cousin and whose daughter married a man who was first cousin to both her mother and father.

The would-be aristocratic families in America were also subject to the same condemnation. Reverend Charles Brooks - Unitarian minister in Massachusetts, progressive educational reformer, Professor of Natural History, staunch abolitionist, and a key character in the cousin marriage debate - wrote an article in 1856 entitled 'Laws of Reproduction, Considered with Particular Reference to the Intermarriage of FirstCousins'. In this article, Brooks (1856: 240) commented upon a specific family from among the aristocratic elite of Virginia, 'where blood relations have intermarried much, in order to keep the property in the family'. In this family, a Fredericksburg man had reported, such intermarriage had been repeated over the generations 'until there cannot be found in three or four of them a sound man or woman. One has sore eyes, another scrofula, a third is idiotic, a fourth blind, a fifth bandy-legged, a sixth with a head about as large as a turnip, with not one of the number exempt from physical or mental defects.' Clearly the intermarrying Virginia aristocracy was as destined to degenerate and disappear as the European nobility.

There is a thread of fear that runs through this literature about the potential for cousin marriage to create a caste system. At the end of his 1856 article, Brooks expressed his concern about the ill effects of 'the great fact of caste' among many cultures of the world (South Sea Islanders, Africans, American Indians, Jews, and Gypsies). It is difficult to know, for sure, what Brooks meant by the word 'caste', but, given Brooks' residence near Boston, his condemnation of 'caste' endogamy surely also speaks to the ascendency of the aristocratic class known as the Boston Brahmins in that city. ${ }^{10}$

${ }^{10}$ Dr Oliver Wendell Holmes, Sr. (father of the US Supreme Court justice) was apparently the first to publish the term Boston Brahmin in an article in the December 1859 issue of Atlantic Monthly entitled 
In 1861, Edward Crossman (1861: 402, emphasis added) considered the practice of livestock in-breeding for specific traits and questioned - with evident concern for consequences for citizenship and civilisation - whether similar practices should be extended to humans:

But are the same results desirable in the reproduction of the human race? Is it not directly the contrary? Is not the man the best citizen, whose mental and bodily powers are most evenly balanced? Would the idea of maintaining through successive generations distinct breeds of statesmen, physicians, clergymen, soldiers, prize-fighters, and jockeys, be agreeable to our notions of civilisation? No! what we desire is to maintain the members of the human family as far as possible in equilibrium; to advance in the mass, to progress altogether [sic].

Here, in his analogy with animal in-breeding, Crossman suggests 'in-and-in' marriage among humans is key to the creation of humoral disequilibrium and unhealthy hierarchical disparities of breeding, pedigree, and privilege that are directly counter to the humoral equilibrium necessary for the human family to advance and progress all together 'in the mass'.

More broadly, all these commentators assessed that 'in-and-in' marriage produced embodied distinctions of hereditary rank that were simultaneously personal, familial, and political - defining the infrastructure of both the little and big commonwealths in aristocratic and monarchical societies. To speak of the disease, degeneration, and demise of individuals and family lines was - in this embodied hierarchy — necessarily to speak of the disease, degeneration, and demise of the aristocratic and monarchical body politic.

\section{HUMORAL THEORIES OF HEREDITARY INTENSIFICATION AND LEVELLING}

In order to break up the power of hereditary status, it was necessary not only to reconfigure the relations between the big and little commonwealths, between political types and marital types, but also to reshape understandings of the health and hereditary consequences of in- and out-marriage. I want to pause for a moment in my argument to explore a conceptual terrain quite foreign to modern medical sensibilities, for it was in the liminal space of mid-19th-century medicine-in which humoral

'The Brahmin Caste of New England', which was later reprinted as the first chapter in his novel, Elsie Venner: A Romance of Destiny (1861). Dr Holmes, himself from a Boston Brahmin family, clearly meant to characterise what he referred to as a hereditary 'aristocratic' class noted for its wealth, its endogamous marriages, and its ties to the founding families of the Massachusetts Bay Colony. 
theories of health, disease, and heredity continued to be dominant and before the concepts of either genetics or germ-specific disease had been firmly established around the turn of the century - that the re-evaluation of cousin marriage was carried out.

Importantly for our story, Carlos López-Beltrán (2007:107) contends that the concept of biological heredity was largely worked out by medical men in relation to the ideas of hereditary diseases. ${ }^{11}$ Medical historian Charles Rosenberg paints a picture of the 19th-century conceptual landscape of heredity and disease as a continuum. At one end were diseases that were clearly understood to be infectious and contagious - such as smallpox, influenza, cholera, and acute fevers - even if specific pathogens or modes of contagion had not yet been determined. At the other end were a small number of unmistakably hereditary conditions such as colour blindness or polydactylism (Rosenberg 1976: 30-1). But that left a third class of ailments - chronic diseases, such as asthma, cancer, gout, mental illness, tuberculosis, scrofula, epilepsy, syphilis, and heart disease. Such conditions, although not perceived as clearly hereditary, came to be seen as 'hereditarily entailed'. The concept of 'hereditary entailment' -or, more technically, 'diathesis' — was developed to account for diseases without remedy, whose causes were indeterminate and puzzling due to the fact that their intergenerational transmission was irregular and unpredictable (Rosenberg 1976: 29, Ackerknecht 1982: 321, Lubinsky 1993: 76, Olby 1993: 412-15, Cartron 2007: 161, Wilson 2007: 135-6). ${ }^{12}$ The indeterminacy inherent in the idea of 'hereditarily entailed'

\footnotetext{
${ }^{11}$ It is also critical to note that, according to López-Beltrán (2007: 105), over the course of the 19th century, the notion of biological heredity began to coalesce around an analogy between the transmission of wealth and other legal properties and the transmission of similar physical traits between parents and offspring'like' reproducing 'like'. However, this analogy underwent what he calls (2007: 106; see also 1994) an 'ontological drift ... from the superficial transmission of general features, such as land or temperament, to a deep-rooted persistence of peculiar powers and dispositions, linked in an essentialist way to family and race'. As the concept of heredity came to be used to refer to the specific mechanism that governs the intergenerational transmission of particular biological properties, the legal and property significations became obsolete (López-Beltran 2007: 106; see also Müller-Wille \& Rheinberger (2007, 2012).

${ }^{12}$ In addition, and more specifically, Erwin Ackernecht (1982: 321) notes that the word diathesis pointed to those diseases with generalised symptomologies - 'with the tendency to latency, recidivism and metastasis' - that challenged the new theories of localism being developed in Parisian medicine in the early 19th century (see also Olby 1993: 414, Waller 2002: 413). That is, in the absence of the localised lesions that the Paris researchers had discovered in relation to other diseases, the very generalised, systemic, and incurable nature of such chronic maladies not only escaped explanation in the terms of localised pathology, but also found a reasonable explanation in the systemic framework of humoral theory. Indeed, the concept of diathesis flourished in the gaps created between the development of an understanding of both localised pathology and germ theory of disease, on the one hand, and the development of effective therapies, which lagged far behind, on the other (Shyrock 1974, Rosenberg 1979, Ackernecht 1982, Waller 2002). Indeed, Waller (2002: 425) suggests, that the 'maladies most commonly identified as heritable were, in the opinion of most doctors, without remedy'.
} 
conditions - sprawled uneasily as these conditions were between clearly infectious and clearly hereditary diseases - is significant for our story because many of the conditions attributed to the 'evil' effects of cousin marriage were actually infectious diseases.

Although researchers - primarily in France and Germany - made great strides in identifying specific bacteria and viruses for specific diseases in the last decades of the 19th century (Starr 1982: 135), Gerald Grob (2002: 194) maintains that a real 'understanding of many infectious diseases, whether of bacterial or viral origin, was either lacking or incomplete at the turn of the century'. Moreover, even if pathogens for specific diseases had been identified, there were few therapeutic measures to treat diseases - a fact that Rosenberg (1979: 16-19) contends ensured that humoral medicine remained in force through the end of the century.

How, then did humoral theories of health, disease, and heredity intersect with the changing evaluations of cousin marriage? Under classical humoral theory, a person's constitutional endowment was composed of a particular configuration and relative balance of the four bodily humours - blood, phlegm, yellow bile, and black bile (although the number and names differ with different authors). Staffan Müller-Wille and Hans-Jörg Rheinberger (2012: 53) explain:

Each of these humors was associated with a pair of qualities, and the bodily constitution or 'temperament' of a person was determined by the mixture of the humors. Depending on which of the humors and associated qualities predominated, one thus distinguished between sanguine (hot and wet), phlegmatic (cold and wet), choleric (hot and dry), or melancholic (cold and dry) temperaments (see also Rosenberg 1976: 29-30, Waller 2002: 436-7, 2003: 53-4).

Health depended upon maintaining a "normal mean"13 or equilibrium and harmony between the four humours, ${ }^{14}$ and this equipoise, Dr Samuel Merrifield Bemiss

\footnotetext{
${ }^{13}$ In his article, 'The Intermarriage of Relations', Dr Nathan Allen (1869: 270-1) asserted that the original standard for humoral balance - which included no excesses and no deficiencies - was defined in God's original creation, but, 'by man's course of disobedience and rebellion, he has lost ... that harmony and perfection in his physical organism which he has never yet been able to regain'.

${ }^{14}$ Coinciding with the idea of a systemic humoral constitution was a conception of therapeutics that was equally systemic, and aimed at re-establishing the internal equilibrium of the humoral constitution of the body. Indeed, up through the Civil War, medicine in the United States was dominated by systemic or monistic understandings of disease pathology and therapeutics. Paul Starr (1982: 38-9) observes that 'Disease was the result of a single, underlying condition that affected the entire constitution; ... The entire focus of treatment was on the patient's symptoms, which were regarded, not as signs of the disease, but as the disease itself' (see also Shryock 1974: 29-31). These symptoms were understood by reference to a generalised theory of causality and were treated by a generalised therapeutic toolkit that regulated bodily inflows and outflows to reestablish internal equilibrium and balance. 'Logically enough', Rosenberg (1979: 7) says, 'drugs were not ordinarily viewed as specifics for particular disease entities;
} 
(1857: 374) noted, 'may be readily disarranged by giving undue predominance to any particular constitutional phase. The slighter deviations from normal mean would constitute individual or family peculiarities; while more marked perversions become morbid manifestations, and infirmity results. ${ }^{15}$

An unhealthy imbalance could be caused by an excessive predominance of one humour over the others in one's inherited constitution - an imbalance that, in itself, could predispose a person to particular diseases (Allen 1869). But it could also be caused by a wide range of other causes. On the one hand, the constitutional endowment of an individual could be influenced by the state of health or illness - or by particular events, accidents, and emotional states - experienced by the mother not only during fetal gestation but also during the nursing of an infant, who remained malleable until weaning (A Physician 1831: 16-19, Rosenberg 1976: 28, De Renzi 2007). ${ }^{16}$

On the other hand, one's constitutional endowment could be influenced by everyday life habits (such as alcoholism or masturbation), by life conditions (such as poverty, over-work, or emotional stress), by life-cycle events (such as puberty, menstruation, or menopause), not to mention by regional or seasonal climate differences (Bemiss 1857, Rosenberg 1979: 6).

Significantly, these acquired traits and behaviours - if 'riveted in the habit' by 'repeated action' (Waller 2002: 440-2) — could fundamentally change one's underlying constitutional structure, the effects of which could be transmitted to one's offspring (Rosenberg 1976: 27, Lubinsky 1993: 77, Olby 1993: 419, Waller 2003: 53-4, Cartron 2007: 160, López-Beltrán 2007: 107-11, Müller-Wille \& Rheinberger 2007: 3-4). ${ }^{17}$

material medica texts were generally arranged not by drug or disease, but in categories reflecting the drug's physiological effects: diuretics, cathartics, narcotics, emetics, diaphoretics'. The very idea that there might be a specific drug tailored to the treatment of a specific disease was met with skepticism and accusations of quackery (Rosenberg 1979: 6, 7).

${ }^{15}$ Allen (1869: 283) says this quote is from a Dr Prichard (James Cowles Prichard?) Bemiss puts the name (Pritchard) in parenthesis following a long paragraph with no quotation marks.

${ }^{16}$ Medical men in Europe and the United States engaged in a vigorous debate-specifically in relation to disease - in their attempts to differentiate what was transmitted or not in the act of generation: that is, what was transmitted in first solidifications of seminal humours and what came later via the placenta, lactations, motions, and imaginations of the mother, etc. (López-Beltrán 2007: 109-11, 114-15).

${ }^{17}$ The concept of diathesis generated considerable debate about the relationship between acquired and constitutional traits, characteristics, and propensities. At the centre of these debates were questions as to whether, when, and how acquired traits might become fixed (and inheritable) constitutional endowments. Some argued that hereditary diseases were 'firmly rooted in a largely unchanging constitution' (Waller 2002: 439). Others argued that acquired traits or diseases — such as alcoholism or scrofula — could become fixed in a person's constitutional endowment at various moments (particularly in and around conception), or if they had, by 'repeated action', so fundamentally changed the underlying constitutional structure (Waller 2002: 440-2, Wilson 2007: 135-6). Once lodged in the underlying structure, disease diatheses would be subject to transmission across the generations through inheritance. 


\section{Marriage as a prophylactic against and an intensifier of 'evil' effects}

This humoral and hereditary logic suggested that it mattered mightily whom one married. Marriage was widely understood to be capable of altering the constitutional endowments and hereditary entailments of one's children and future descendants, both for the better and for the worse (Rosenberg 1976: 31-2, 39-42, Waller 2002: 411, 428-29, 431-32, 2003: 55, Cartron 2007: 168-9, Wilson 2007: 140-5, Paul \& Spencer 2016: 54). Parents therefore examined the relatives of their children's suitors for signs of a wide range of hereditary conditions, such as mental illness or scrofula; and, conversely, many families felt compelled to conceal evidence of such hereditary entailments to prevent the marital prospects of their children from being irreparably damaged (Waller 2002: 411, 433, Cartron 2007: 168, Wilson 2007).

In popular advice books, physicians counselled that choosing the right marital partner could compensate for one's own humoral imbalances or hereditary predispositions, with positive consequences for one's descendants (A Physician 1831, Clark 1835, Ticknor 1839, Pendleton 1871). For instance, in the Guide to Mothers and Nurses in the Management of Young Children: With Reference to Hereditary, or Family Diseases, Caleb Ticknor (1839: 239-40) warned that, in the case of those with hereditary predispositions, 'continued intermarriage between members of the same family, is such, that very often, whole families become extinct, in the second or third generation; or, if the race is perpetuated, those who survive are feeble, both in intellect and body'; however, the author goes on to say that 'if a different course were pursued,- -if those who inherit predisposition to disease, were to contract matrimonial alliances with the healthy and robust, - - the third generation instead of becoming extinct, would have recovered the original health and vigour of their family.' Likewise, Sir James Clark, in his Treatise on Tubercular Phthisis (1834) urged care and consideration in choosing a spouse. Waller (2002: 431) relates that Clark 'was confident that with prudent marriages, and a scrupulous attention to diet and living environment, "the predisposition which is so often entailed on ... offspring might be checked, and even extinguished." But, he [Clark] added, so difficult is the hereditary taint to eradicate that it takes at least a "few generations" to effect a full cure' (see also Cartron 2007, Wilson 2007). Observing the conceptual entwinement of hereditary biology and wealth, Rosenberg (1976: 31-2) notes that 'Physicians and moralists warned from the late eighteenth century on ... [that] [c]onstitutional disease could be entailed as irrevocably as lands and rents.' He quotes the Scottish author, Dr William Buchan, who wrote in his immensely popular volume, Domestic Medicine - read on both sides of the Atlantic - that 'Family constitutions are as capable of improvement as family estates; and the libertine, who impairs the one, does greater injury to his posterity, 
than the prodigal, who squanders away the other' (Rosenberg 1976: 31-2). ${ }^{18}$ Thus, in this proto-eugenic framework (Paul \& Spencer 2016), marriage could be mobilised as a prophylactic against existing humoral imbalances and hereditary entailments and, over time and with great care, it could eradicate specific hereditary maladies from a family line.

But marriage could also intensify a shared humoral imbalance. This was the lesson embedded in Dr Samuel Gridley Howe's (1848a) influential Report Made to the Legislature of Massachusetts upon Idiocy (see also 1848b). Howe determined that idiocy was caused by three parental conditions and habits: 'low condition', ${ }^{19}$ alcoholism, and (worst of all) masturbation. Cousin marriage entered the picture because he believed that cousins tended to share the same constitutional endowments, which were 'intensified' - with catastrophic consequences - in their progeny. Howe's remarkable Report, which was widely referenced, was perhaps the first major study in America that linked cousin marriage to specific forms of 'degeneration'.

However, it was the work of Dr Samuel Merrifield Bemiss that was key to turning the tide against cousin marriage in mid-19th-century America. Born in Kentucky in 1821, Bemiss was a physician, who held various academic positions in medicine at the University of Louisville and became an active member and office holder in the fledgling American Medical Association (AMA) after it was founded in 1847 (Lorenz n.d.). It was under the auspices of the AMA that Dr Bemiss undertook to consolidate a number of studies of consanguineous marriage to test two interlinked propositions: that people who are related will more likely share the same temperaments and predispositions; and that the 'evil' effects of the intensification of the same temperaments and predispositions increase with the closeness of relation. In his Report on the Influence of Marriages of Consanguinity upon Offspring published in the 1858 Transactions of the AMA, Dr Bemiss compiled an astounding 86 pages of tables summarising the conditions and consequences of 873 consanguineous marriages in a stunning tabulation of numbers

\footnotetext{
${ }^{18}$ There is a fairly explicit class critique in some of some of these advice manuals, in which writers advise strongly against marrying solely for concerns of wealth and luxury without regard for health, or solely for the prospects of rank or inheritance without regard for hereditary consequences. Wilson (2007: 141), points out that the progressive-minded Edinburgh-trained physicians, Dr Buchan and Dr Erasmus Darwin (grandfather of Charles Darwin), were both critical of the endogamous marital patterns of the British upper class, which fostered the inheritance not only of aristocratic rank and power but also of so-called aristocratic diseases, such as gout. Similarly, on the American side of the Atlantic, Ticknor (1839: 239) in the Guide noted above, argued that the 'intermarriages between different families of the wealthy class' can often have just as dire consequences as intermarriages within the same family', the reason being that 'there is a similarity in the habits of living, generally all tending to create some peculiar predisposition, which, sooner or later, is manifested'.

${ }^{19}$ There were certain visual markers that pointed to the 'low condition' of parents and children. Among the most notable, for Howe (1848a: 80-1), was scrofula - a tubercular disease of the lymph glands that was common throughout the 19 th century.
} 
and detailed observations. Bemiss's (1858: 325) bold conclusion was often quoted as evidence in subsequent arguments against cousin marriage:

It will be perceived that parental infirmities are entailed with great certainty upon the offspring, and this, in the opinion of the reporter, constitutes the strongest argument against the intermarriage of relatives; the fact that family peculiarities, tendencies, and infirmities, either of mind or body, which may be so slight on the part of parents as to remain latent, become so exaggerated by this 'intensifying' of the same blood, that they are in the child prominent and ruinous defects.

Although the data were impressive in scale and detail, there were two main problems with Bemiss's analysis. First, he never actually undertook an analysis that would demonstrate whether the constitutional predispositions or temperaments of parents were, in fact, 'entailed with great certainty' upon - let alone intensified intheir offspring. Second, the statistics he marshalled did not consistently support his proposition that the effects of this intensification increase with the closeness of relation (1858: 332). Indeed, in both his 1857 and 1858 studies, the "percentage of the "defective" in children of third cousins is actually greater than in the offspring of second or even of first cousins' (Withington 1885, quoted in Ottenheimer 1996: 56). ${ }^{20}$

In addition, with the benefit of hindsight, we know that many of the diseases that Dr Bemiss considered 'hereditarily entailed' - in particular the tubercular diseaseswere in fact infectious diseases ${ }^{21}$; and that many of the conditions - such as blindness, deafness, mental retardation, respiratory ailments, and structural deformities - that were often attributed to the ill effects of cousin marriage could be caused by infectious diseases as well as by the harsh, so-called 'heroic', cures associated with humoral medicine - in particular the use of calomel, a form of mercury (mercurious chloride).

Nevertheless, firmly believing in the certainty of his conclusions, Dr Bemiss imagined a position of social advocacy unique to a new class of trained and certified 'regular' physicians. His Report provided a clear prescription for action in the interests of public health: 'There is no better mode of maintaining this happy mean [i.e., equilibrium] of temperament than by admixture of types of constitution possessing no family identity' (1858: 374; see also Brooks 1856: 237, Allen 1869: 284-85). Dr Nathan Allen (1869: 284-85), writing eleven years later, concurred with Dr Bemiss's conclusions:

\footnotetext{
${ }^{20}$ Bemiss's statistics have been critiqued by 19 th-century commentators (e.g., Bell 1859, Withington 1885) as well as more recent ones (e.g., Ottenheimer 1996: 55-6, Kuper 2009: 248).

${ }^{21}$ To the extent that diagnoses were based on external signs and symptoms (Grob 2002: 110), which were perceived through the unaided senses, rather than diagnostic tests for specific pathogens, not only was it difficult to distinguish between hereditary and infectious diseases, but the classificatory differentiation of diseases and treatments were also difficult to assess. For instance, any distinction between tuberculosis and a host of other pulmonary diseases and conditions was largely impossible to determine from symptoms alone (Grob 2002: 177).
} 
Admitting the fact that there is a greater resemblance, likeness, similarity, in family connections, extending sometimes to almost every organ in the body ... and that, when these connections form matrimonial alliances, it must have, according to the laws of hereditary descent, a marked and decided effect upon their offspring - if, in addition ... these same parties should both have internal parts of the body imperfectly developed, morbid or diseased, the effect must be still greater and more injurious. The nearer the relation, and the more imperfect and diseased the bodies of both are, the effects become still more obvious as well as injurious.

But it was the Bemiss Report, with its impressive 86 pages of data, that established what was - for 19th-century American readers - convincing biological evidence that turned the aristocratic logic of cousin marriage upside down. No longer a positive means for retaining the hereditary purity of an aristocratic class, cousin marriage displayed the 'evil' degenerative effects - on health and heredity - of the intensification of temperaments. By contrast, out-marriage was no longer seen to corrupt the purity of aristocratic lines but rather to ensure the health, vitality, and temperamental equipoise of descendant lines.

\section{THE ARGUMENTS FOR OUT-MARRIAGE- AND ITS RACIAL LIMITATIONS}

Opponents of cousin marriage situated this medical argument within a larger debate about the consequences of in- and out-marriage to improve or degenerate hereditary predispositions not only for family lines but also for populations, nations, and, ultimately, for contrasting political types.

Populations in isolated communities - for instance, in the Alps or on offshore islands - were often cited as prime exemplars of the degenerative effects of cousin marriage. Dr Allen (1869: 247) drew the general conclusion that, in isolated places with 'little change in society from immigration', the effects of the intermarriage of relatives over several generations 'are marked by a loss of mental power and strength, of boldness and energy of character, with an increase of scrofulous and consumptive complaints, of defects in one or more of the senses, and not unfrequently of deformities of the body'. He goes on to suggest that such people are incapable of any 'real improvement or progress in securing the most important objects of life, but, after remaining a while in a kind of stationary state, they gradually decline both in numbers and character'.

Over against the degenerative effects of in-marriage in the context of isolated populations, commentators argued for the positive effects of human migrations and the mixing of populations, which were presumed to enhance the vitality of descendants 
beyond that of the parent populations. Dr Bemiss (1857:375) quotes an author named Benton, who maintained that it is part of God's providence 'that there should be (as usually there is), once in 600 years, a transmigration of nations to amend and purify their blood, as we alter seed upon our land'. And Reverend Brooks (1856: 238) advocated for the power and vitality born of out-marriage admixtures in face of what he saw as evidence that the descendants of cousin marriages seemed to lack 'that entire and symmetrical unfolding or equilibrium of the physical, intellectual, and moral powers which constitute a whole man'. Brooks surmised (1856: 245) that 'When the great laws of amalgamation are properly understood', it would not be difficult to see the positive effects of various mixings:

It will not be difficult to explain the surpassing beauty of the Circassians and Georgians; or ... the stronger and larger limbs of ... [the Irish] where they have intermarried with English settlers and the Lowlanders of Scotland. It will not be difficult to explain the superior physical and mental qualities of the mixed races in Paraguay, in contrast with their neighbours; or of the offspring of the Dutch in their union with Hottentots.

Just five years before the onset of the American Civil War, the fact that Brooks would assert positive consequences for cross-race 'mixings' was notable.

To come full circle and link the political, marital, and medical-hereditary arguments again, it is clear that these admixtures of populations were seen, in the American case, as part of the levelling effect that was key to the special vitality and progress of the republican experiment. Dr Bemiss (1857: 377), arguing that human vigour and progress clearly followed from the 'ingrafting of nations differing in constitution and temperament', went on to note that 'the extraordinary activity and energy of the American people are due to the composite nature of their blood'.

Reverend Brooks (1856: 246) drew together the marital and political connections even more tightly — and enthusiastically — in the last paragraph of his article:

Will not our country furnish the most wonderful example of the effects of intermarriages with different castes of the Caucasian race? When the people of these United States become a mixture of English, Scotch, Irish, Germans, and French, will they exhibit a strength of body and an intelligence of mind, a true inborn energy and moral power, which do not equally signalize either of the nations from whom they sprang? Under the fostering care of a truly republican and Christian government, will they advance in science, arts, agriculture, commerce, and manufactures, and all the blessings of a religious civilization and political equality, as no one of their parent nations has? Let us hope that it is the appointed destiny of our free and prosperous land, to exhibit a higher development of human attributes than has yet blessed or astonished mankind.

If cousin marriage intensified and magnified temperamental taints and hereditary 
entailments, causing disease, degeneration, and the decline of family lines, entire populations, and the old aristocratic political order, then clearly out-marriage provided a kind of levelling admixture of temperaments that recalibrated the equipoise necessary for a healthy constitution - of individuals, families, populations, and democratic republics.

\section{The racial limits of out-marriage}

But there was catch to this argument: the cultural politics of race in antebellum America. To think about the racial limits of this levelling logic of out-marriage and its relation to ideas of national belonging, I want return to two of our key mid-century opponents of cousin marriage- Reverend Brooks and Dr Bemiss - whose claims to authority were differently shaped and who were very differently situated relative to the issues of race and the impending Civil War. Both men saw the migrations and mixtures inherent in American social relations to be critical to the special destiny of the American republic. But their estimation of who was to be included in that logic of mixtures and special destinies differed somewhat.

As we just saw, in the last paragraph of his 1856 article, Reverend Brooks explicitly connected out-marriage to the 'blessings of ... political equality' in 'a truly republican and Christian government'. However, despite the fact that Brooks was an avid abolitionist - who had argued for the superiority of progeny born of cross-race mixings earlier in his article, and who, in 1859, would travel to the South to witness the "horrors' of slavery (Brooks 1859) - it is not evident how far he was willing to go to break down racial divides in America through marriage in order to achieve that 'blessed' appointed destiny. Here, his wildly idealistic vision for America is limited to the 'castes' of the 'Caucasian' race; and we know that, as an advocate for the American Colonization Society, he favoured the resettlement of enslaved African Americans in Africa. In his Portraits of Eminent Americans Now Living, John Livingston (1854: 484) reported that Brooks considered the removal of African Americans to Africa 'as the most feasible plan for Christianizing Africa, for destroying the slave trade, and for restoring the black man to his native skies and his inalienable rights'. Whether these sentiments would have affected his understanding of the cross-racial limits of outmarriage within the United States is unknown.

Dr Bemiss was much more explicit about the cross-racial limits of out-marriage. He had argued that human vigour and progress clearly followed from the 'ingrafting of nations' and that 'the extraordinary activity and energy of the American people are due to the composite nature of their blood' (1857: 377). But in the next sentence he was quick to recast the positive implications of such mixing. 'This rule', Bemiss (1857: 377) equivocated, 'seems subject to some qualification; for there certainly exist 
strong reasons to believe that matrimonial alliances between the greatest possible contrast to be found on our globe - the negro and Caucasian races, for instance - are not favourable to the most vigorous propagation of the species. I do not look upon mulattoes as hybrids, but think they exhibit less of vigor and vital force than are found in crosses where there is less contrast.' Dr Bemiss did not take an extreme polygenetic position, which held that 'Caucasians' and 'negroes' were distinct species whose sexual union would result in sterile hybrids. Yet he claimed that interracial unions were 'certainly' productive of less vigorous offspring and reduced fertility. By refusing to extend to interracial marriages the positive effects of out-marriage, he gave medical authority to the marital and hereditary logic of racial hierarchy and to the racial limits of national belonging in antebellum America. Six years after he wrote this statement, Dr Bemiss fled Louisville in the middle of the night, under threat of arrest for being a Southern sympathiser, and crossed the border into Tennessee to become a doctor in the Confederate Army from 1863 until the end of the war in 1865.22

But Dr Bemiss's grand synthesis of the evidence against cousin marriage - despite its many flaws and his Southern sympathies - had a considerable effect in turning the tide against consanguineous unions. Of the states that had entered the union before 1861, Ottenheimer (1996: 37) observes, none had prohibited first cousin marriage, but by the 1880s, 'thirteen states and territories had passed legislation forbidding cousins from marrying' and by 1908 sixteen states had. Currently thirty-one states prohibit or place restrictions on first cousin marriage, while it remains legal in nineteen states (Ottenheimer 1996: 37).

\section{CONCLUSION}

If you ask Americans, today, why people no longer marry their cousins, they will readily give you an answer that combines emotional revulsion with an account of genetic causality and scientific progress. However, the stigma and revulsion evoked by cousin marriage today coalesced not with the 20th-century certainties of genetics but in the very peculiar economic, political, and medical circumstances of 19th-century America. During an era of radical social transformation, theorists created a convincing conceptual space through a set of cultural analogies that stigmatised cousin marriage by tying it to the forces of degeneration and decay — of individuals, family lines, nations, and hierarchical polities. It was in this same conceptual space-which

\footnotetext{
${ }^{22}$ After the war, in 1866, Dr Bemiss resigned from his position at the University of Louisville and took up a position in the School of Medicine at the University of Louisiana, where he dedicated himself to teaching and to understanding the problem of yellow fever (see Lorenz (n.d.) for an extended biography of Dr Bemiss).
} 
linked the big and little commonwealths and connected the vitality of the national body politic to that of the family and the individual - that the social ligaments of affection began to be reconfigured to conform to the values of an aspiring - if racially conflicted-democratic republic. And, I would suggest, it is this set of specifically 19th-century political, marital, and medical-hereditary associations that continues to inform debates about place of cousin marriage in so-called modern, democratic societies today.

This history tells us - despite much social theory that argues otherwise- that forms of kinship and marriage still matter in the definition of political formations in state-based societies as much as in so-called kin-based societies (McKinnon 2013, McKinnon \& Cannell 2013); and that attention to the changing contours of the concordances (or discordances) between ideas about domestic and political relations continue to be critical to understanding moments of radical political transformation in contemporary societies. This history also tells us that, to the extent that social systems of hierarchy entail ideas about embodied difference, understanding moments of radical social transformation requires the comprehension of the culturally and historically specific combinatory logics of reproduction and marriage, of heredity, and of health and illness. And it requires a careful tracing of the ways in which these shift in the voices and writings of those deemed to have authoritative knowledgewhether they be in the spheres of religion, medicine, and/or science. And finally, this history tells us just how important the history of medicine and science is to the history of political and social transformations and to the history of narratives about what has come to count - at least in Euro-American societies - as politically 'modern' and 'progressive'.

Acknowledgements: It was a great honour to be invited by the British Academy to present the 2018 Radcliffe-Brown Lecture in Social Anthropology, and I am grateful to the Academy for their generous hospitality. In particular, I am indebted to Professors Marilyn Strathern and Janet Carsten, who graciously hosted my lectures in London and Edinburgh, respectively. This paper benefitted significantly from constructive readings by and conversations with Marilyn Strathern, Deborah Johnson, and China Scherz. Over the years I have been working on the larger project of which this paper is a part, I have been supported by fellowships from a number of institutions- the National Endowment for the Humanities, the University of Virginia, the Virginia Foundation for the Humanities, the School for Advanced Research in Santa Fe, NM, and the (2017-2018) Kinship and Politics Working Group at the Center for Interdisciplinary Research at the University of Bielefeld - for which I wish to express my deepest appreciation. 


\section{REFERENCES}

Abby, R. (1999), 'Back to the Future: Marriage as Friendship in the Thought of Mary Wollstonecraft', Hypatia, 14: 78-95. https://doi.org/10.1111/j.1527-2001.1999.tb01053.x

Ackerknecht, E. H. (1982), 'Diathesis: The Word and the Concept in Medical History', Bulletin of the History of Medicine, 56: 317-25.

Allen, N. (1869), 'The Intermarriage of Relations', The Quarterly Journal of Psychological Medicine and Medical Jurisprudence, 3: 244-97. https://doi.org/10.1097/00000441-186910000-00048

A Physician (1831), Hints to a Fashionable Lady (New York, Charles S. Francis).

Arner, G. B. L. (1908), 'Consanguineous Marriages in the American Population', in The Faculty of Political Science of Columbia University (ed.), Studies in History, Economics, and Public Law, vol. 31 (New York, Columbia University), 347-440.

Arni, C. (2006), 'Rivalry and Friendship in the Heterosexual Couple: Challenges to Discourses of Society in Late 19th and Early 20th Century Europe', in Occasional Papers from the School of Social Science, Institute for Advanced Study, April 2006, Paper Number 25.

Baptist, E. E. (2014), The Half Has Never Been Told: Slavery and the Making of American Capitalism (New York, Basic Books).

Basch, N. (1995), 'From the Bonds of Empire to the Bonds of Matrimony', in D. T. Konig (ed.), Devising Liberty: Preserving and Creating Freedom in the New American Republic (Stanford CA, Stanford University Press), 217-42.

Bell, J. (1859), 'The Effects of the Consanguinity of Parents upon the Mental Constitution of the Offspring', Boston Medical and Surgical Journal, 60: 473-84.

https://doi.org/10.1056/NEJM185907140602402

Bemiss, S. M. (1857), 'On Marriages of Consanguinity', Journal of Psychological Medicine and Mental Pathology, 10: 369-79.

Bemiss, S. M. (1858), 'Report on the Influence of Marriages of Consanguinity upon Offspring', Transactions of the American Medical Association, 11: 319-425.

Bittles, A. H., \& Black, M. L. (2015), Global Patterns and Tables of Consanguinity. http://consang.net

Brooks, C. (1856), 'Laws of Reproduction, Considered with Particular Reference to the Intermarriage of First-cousins', Proceedings of the American Association for the Advancement of Science, 236-46.

Brooks, C. (1859), Brief Record of a Journey in Georgia, North \& South Carolina, Virginia, Washington, Maryland, Philadelphia, \& New York, 1859, New York Historical Society Manuscript Collection.

Brown, J. S. (1951), 'Social Class, Intermarriage, and Church Membership in a Kentucky Community', American Journal of Sociology, 57: 232-42. https://doi.org/10.1086/220940

Caldwell, C. (1834), Thoughts on Physical Education: Being a Discourse Delivered to a Convention of Teachers in Lexington, KY., on the 6th and 7th of Nov., 1833 (Boston, MA, Marsh, Capen and Lyon).

Caldwell, C. (1836), Thoughts on Physical Education, and the True Mode of Improving the Condition of Man (Edinburgh, Adam and Black).

Cashin, J. E. (1990), 'The Structure of Antebellum Planter Families: "The Ties that Bound Us Was Strong"', Journal of Southern History, 56: 55-70. https://doi.org/10.2307/2210664

Cartron, L. (2007), 'Degeneration and "Alienism" in Early Nineteenth-century France', in S. MüllerWille \& H.-J. Rheinberger (eds), Heredity Produced at the Crossroads of Biology, Politics, and Culture, 1500-1870 (Cambridge MA, MIT Press), 155-74.

Censer, J. T. (1984), North Carolina Planters and their Children: 1800-1860 (Baton Rouge, LA, Louisiana State University Press).

Clark, J. (1834), Treatise on Tubercular Phthisis, or Pulmonary Consumption, reprinted from the Cyclopaedia of Practical Medicine (London, Marchant). 
Cott, N. (2000), Public Vows: A History of Marriage and the Nation (Cambridge, MA, Harvard University Press).

Crossman, E. (1861), 'On Intermarriage of Relations as a Cause of Degeneracy of Offspring', British Medical Journal, 1: 401-2. https://doi.org/10.1136/bmj.1.15.401-b

De Renzi, S. (2007), 'Resemblance, Paternity, and Imagination in Early Modern Courts', in S. MüllerWille \& H.-J. Rheinberger (eds), Heredity Produced at the Crossroads of Biology, Politics, and Culture, 1500-1870 (Cambridge, MA, MIT Press), 361-83.

Faber, B. (1972), Guardians of Virtue: Salem Families in 1800 (New York, Basic Books).

Farrell, B. (1993), Elite Families: Class and Power in Nineteenth-century Boston (Albany, NY, State University of New York Press).

Filmer, R. (1680), Patriarcha: The Naturall Power of Kinges Defended against the Unnatural Liberty of the People, in J. P. Sommerville (ed.), Sir Robert Filmer: Patriarcha and Other Writings (Cambridge, Cambridge University Press, 1991), 1-68. https://doi.org/10.1017/CBO9780511812644.007

Fliegelman, J. (1982), Prodigals and Pilgrims: The American Revolution against Patriarchal Authority, 1750-1800 (Cambridge, Cambridge University Press).

Frazer, E. (2008), 'Mary Wollstonecraft on Politics and Friendship', Political Studies, 56: 237-56. https://doi.org/10.1111/j.1467-9248.2007.00670.x

Gordon, S. B. (2002), The Mormon Question: Polygamy and Constitutional Conflict in Nineteenth-century America (Chapel Hill, NC, University of North Carolina Press).

Gough, R. J. (1989), 'Close-kin Marriage and Upper-class Formation in Late-eighteenth-century Philadelphia', Journal of Family History, 14: 119-36. https://doi.org/10.1177/036319908901400202

Griffen, S. \& Griffen, C. (1977), 'Family and Business in a Small City: Poughkeepsie, New York, 18501880 ', in T. K. Hareven (ed.), Family and Kin in Urban Communities, 1700-1930 (New York, New Viewpoints), 144-63.

Grob, G. N. (2002), The Deadly Truth: A History of Disease in America (Cambridge, MA, Harvard University Press).

Haines, M. (no date), 'Fertility and Mortality in the United States', EH.net (Economic History Association) http://eh.net/encyclopedia/fertility-and-mortality-in-the-united-states/ (accessed September 8, 2018).

Hall, P. D. (1977), 'Family Structure and Economic Organization: Massachusetts Merchants, 1700-1850', in T. K. Hareven (ed.), Family and Kin in Urban Communities, 1700-1930 (New York, New Viewpoints), 38-61.

Hall, P. D. (1978), 'Marital Selection and Business in Massachusetts Merchant Families, 1700-1900', in M. Gordon (ed.), The American Family in Social-historical Perspective, 2nd edn (New York, St. Martin's Press), 101-14.

Hill, L. \& McCarthy, P. (1999), 'Hume, Smith and Ferguson: Friendship in Commercial Society', Critical Review of International Social and Political Philosophy, 4: 33-49. https://doi.org/10.1080/13698239908403290

Holmes, O. W. (1861), Elsie Venner: A Romance of Destiny, in The Writings of Oliver Wendell Holmes, vol. 5, Riverside Edition (Boston, MA Houghton, Mifflin, 1894).

Howe, S. G. (1848a), Report Made to the Legislature of Massachusetts upon Idiocy (Boston, MA, printed from the State Edition by Coolidge \& Wiley).

Howe, S. G. (1848b), 'The Causes and Prevention of Idiocy', Massachusetts Quarterly Review, 1: 308-31.

Jordan, W. D. (1973), 'Familial Politics: Thomas Paine and the Killing of the King, 1776', Journal of American History, 60: 294-308. https://doi.org/10.2307/2936777

Kulikoff, A. (1976), “ “Throwing the Stocking,” A Gentry Marriage in Provincial Maryland', Maryland Historical Magazine, 71: 516-21. 
Kulikoff, A. (1986), Tobacco and Slaves: The Development of Southern Cultures in the Chesapeake, 16801800 (Chapel Hill, NC, University of North Carolina Press). https://doi.org/10.2307/25142826

Kuper, A. (2009), Incest and Influence: Private Life of Bourgeois England (Cambridge, MA, Harvard University Press). https://doi.org/10.4159/9780674054141

Laslett, P. (1988), 'Introduction', in P. Laslett (ed.), John Locke: Two Treatises of Government (Cambridge, Cambridge University Press), 3-133.

Lévi-Strauss, C. (1963), Structural Anthropology, trans. C. Jacobson \& B. G. Schoepf (New York, Basic Books).

Lévi-Strauss, C. (1969), The Elementary Structures of Kinship, rev edn, trans. J. H. Bell, J. R. von Sturmer, $\&$ R. Needham (Boston, MA, Beacon Press).

Lévi-Strauss, C. (1985), The View from Afar (New York, Basic Books).

Lewis, J. (1987), 'The Republican Wife: Virtue and Seduction in the Early Republic', The William and Mary Quarterly, 44: 689-721. https://doi.org/10.2307/1939741

Lieber, F. (1855), 'The Mormons. Shall Utah be Admitted into the Union?', Putnam's Monthly, 5: 225-36.

Livingston, J. (1854), 'Rev. Charles Brooks, Boston, Massachusetts', in J. Livingston, Portraits of Eminent Americans Now Living (New York, R. Craighead), 480-94.

Locke, J. (1698), Two Treatises of Government, in P. Laslett (ed.), John Locke: Two Treatises of Government (Cambridge, Cambridge University Press, 1988), 137-438.

https://doi.org/10.1017/CBO9780511810268

López-Beltrán, C. (1994), 'Forging Heredity: From Metaphor to Cause, a Reification Story', Studies in the History and Philosophy of Science, 25: 211-35. https://doi.org/10.1016/0039-3681(94)90028-0

López-Beltrán, C. (2007), 'The Medical Origins of Heredity', in S. Müller-Wille \& H.-J. Rheinberger (eds), Heredity Produced at the Crossroads of Biology, Politics, and Culture, 1500-1870 (Cambridge, MA, MIT Press), 105-32.

Lorenz, L. (no date), Medical Leader of the Nineteenth Century: Career of Dr. Samuel Merrifield Bemiss, MS C 454 in the collection of the History of Medicine Division, National Library of Medicine, National Institutes of Health.

Lubinsky, Mark S. (1993), 'Degenerate Heredity: The History of a Doctrine in Medicine and Biology', Perspectives in Biology and Medicine, 37: 74-90. https://doi.org/10.1353/pbm.1994.0056

McKinnon, S. (2013), 'Kinship within and beyond the "Movement of Progressive Societies", , in S. McKinnon \& F. Cannell (eds), Vital Relations: Modernity and the Persistent Life of Kinship (Santa Fe, NM, School for Advanced Research Press), 39-62.

McKinnon, S. (2019), 'Reading the Contested Forms of Nation through the Contested Forms of Kinship and Marriage', in S. Bamford (ed.), The Cambridge Handbook of Kinship (Cambridge, Cambridge University Press), 605-28.

McKinnon, S. (no date), 'Commonwealths of Affections: Kinship, Marriage, and Polity in Eighteenthand Nineteenth-century America', paper presented at the Authors' Conference for the Kinship and Politics Working Group at the Center for Interdisciplinary Studies, University of Bielefeld, 3 December 2018.

McKinnon, S. \& Cannell, F. (2013), 'The Difference Kinship Makes', in S. McKinnon \& F. Cannell (eds), Vital Relations: Modernity and the Persistent Life of Kinship (Santa Fe, NM, School for Advanced Research Press), 3-38.

Montesquieu, Baron de C. de S. (1728), Persian Letters, trans. M. Mauldon (Oxford, Oxford University Press, 2008).

Montesquieu, Baron de C. de S. (1748), The Spirit of the Law, trans. \& eds. A. M. Cohler, B. C. Miller, \& H. S. Stone (Cambridge, Cambridge University Press, 1989). 
Müller-Wille, S. (2007), 'Figures of Inheritance, 1650-1850', in S. Müller-Wille \& H.-J. Rheinberger (eds), Heredity Produced at the Crossroads of Biology, Politics, and Culture, 1500-1870 (Cambridge, MA, MIT Press), 177-204. https://doi.org/10.7551/mitpress/3482.003.0013

Müller-Wille, S. \& Rheinberger, H.-J. (2007), 'Heredity-The Formation of an Epistemic Space', in S. Müller-Wille \& H.-J. Rheinberger (eds), Heredity Produced at the Crossroads of Biology, Politics, and Culture, 1500-1870 (Cambridge, MA, MIT Press), 3-34. https://doi.org/10.7551/mitpress/3482.003.0003

Müller-Wille, S. \& Rheinberger, H.-J. (2012), A Cultural History of Heredity (Chicago, IL, University of Chicago Press). https://doi.org/10.7208/chicago/9780226545721.001.0001

Olby, R. C. (1993), 'Constitutional and Hereditary Disorders', in W. F. Bynum \& R. Porter (eds), Companion Encyclopedia of the History of Medicine, vol. 1 (London, Routledge), 412-37.

Ottenheimer, M. (1996), Forbidden Relatives: The American Myth of Cousin Marriage (Urbana, IL, University of Illinois Press).

Paine, T. (under pseudonym Esop) (1775a), 'Cupid and Hymen. An Original', The Pennsylvania Magazine; or, American Monthly Museum, April: 158-61.

Paine, T. (under pseudonym The Old Bachelor) (1775b), 'Reflections on Unhappy Marriages', The Pennsylvania Magazine; or, American Monthly Museum, June: 263-5.

Paine, T. (1776), Common Sense, in Collected Writings (New York, Literary Classics of the United States, 1955).

Paul, D. B. \& Spencer, H. G. (2016), 'Eugenics without Eugenists? Anglo-American Critiques of Cousin Marriage in the Nineteenth and Early Twentieth Century', in S. Müller-Wille \& C. Brandt (eds), Heredity Explored: Between Public Domain and Experimental Science, 1850-1930 (Cambridge, MA, MIT Press), 49-79.

Pendleton, H. (1871), The Parent's Guide: or, Human Development through Inherited Tendencies (New York, S. R. Wells).

Radcliffe-Brown, A. R. (1930-31), 'The Social Organization of Australian Tribes', in A. Kuper (ed.), The Social Anthropology of Radcliffe-Brown (London, Routledge and Kegan Paul, 1977), 131-74.

Reid, R. M. (1988), 'Church Membership, Consanguineous Marriage, and Migration in a Scotch-Irish Frontier Population', Journal of Family History, 13: 397-414. https://doi.org/10.1177/036319908801300403

Rosenberg, C. E. (1976), No Other Gods: On Science and American Social Thought (Baltimore, MD, Johns Hopkins University Press).

Rosenberg, C. E. (1979), 'The Therapeutic Revolution: Medicine, Meaning, and Social Change in Nineteenth-century America', in M. J. Vogel \& C. E. Rosenberg (eds), The Therapeutic Revolution: Essays in the Social History of American Medicine (Philadelphia, PA, University of Pennsylvania Press), 3-26. https://doi.org/10.9783/9781512819151-002

Sabean, D. W. \& Teuscher, S. (2007), 'Kinship in Europe: A New Approach to Long Term Development', in D. W. Sabean, S. Teuscher \& Jon Mattieu (eds), Kinship in Europe: Approaches to Long-term Development (1300-1900) (New York, Berghahn Books), 10-32.

Shanley, M. L. (1982), 'Marriage Contract and Social Contract in Seventeenth-century English Political Thought', in J. B. Elshtain (ed.), The Family in Political Thought (Amherst, MA, University of Massachusetts Press), 80-95.

Shanley, M. L (1991), 'Marital Slavery and Friendship: John Stuart Mill's The Subjection of Women', in M. L. Shanley \& Carole Pateman (eds), Feminist Interpretations and Political Theory (University Park, PA, Pennsylvania State University Press), 164-80.

Shanley, M. L. \& Stillman, P. G. (1982), 'Political and Marital Despotism: Montesquieu's Persian Letters', in J. B. Elshtain (ed.), The Family in Political Thought (Amherst, MA, University of Massachusetts Press), 66-79. 
Shryock, R. H. (1974), The Development of Modern Medicine: An Interpretation of the Social and Scientific Factors Involved (Madison, WI, University of Wisconsin Press).

Smith, D. B. (1980), Inside the Great House: Planter Family Life in Eighteenth-century Chesapeake Society (Ithaca, NY, Cornell University Press).

Smith, B. C. (2010), The Freedoms We Lost: Consent and Resistance in Revolutionary America (New York, The New Press).

Starr, P. (1982), The Social Transformation of American Medicine: The Rise of a Sovereign Profession and the Making of a Vast Industry (New York, Basic Books).

Steger, F. E. H. (1855), 'Hereditary Transmission of Disease', Nashville Journal of Medicine and Surgery, 8: 177-91.

Strathern, M. (in press), Relations: An Anthropological Exposition (Durham, NC, Duke University Press).

Supple, B. E. (1997), 'A Business Elite: German-Jewish Financiers in Nineteenth-century New York', Business History Review, 31: 143-78. https://doi.org/10.2307/3111848

Ticknor, C. (1839), Guide to Mothers and Nurses in the Management of Young Children: With Reference to Hereditary, or Family Diseases (New York, Taylor and Dodd).

de Tocqueville, A. (1835), Democracy in America, vol. 1 (New York, Vintage Books, 1945).

Vernon, R. W. (1979), 'Marriage and Inheritance in the Blue Ridge', in R. W. Foss, J. V. Atta, \& R. W. Vernon (eds), Patterns in Time: Human Adaptation in the Blue Ridge from 7000 B.C. to 1930 A.D., manuscript in the collection of the author.

Waller, J. C. (2002), “"The Illusion of an Explanation”: The Concept of Hereditary Disease, 1770-1870', Journal of the History of Medicine, 57: 410-48. https://doi.org/10.1093/jhmas/57.4.410

Waller, J. C. (2003), 'Parents and Children: Ideas of Heredity in the 19th Century', Endeavour, 27: 51-6. https://doi.org/10.1016/S0160-9327(03)00058-9

Wiencek, H. (1999), The Hairstons: An American Family in Black and White (New York, St. Martin's Griffin).

Wilson, P. K. (2007), 'Erasmus Darwin and the "Noble" Disease (Gout): Conceptualizing Heredity and Disease in Enlightenment England', in S. Müller-Wille \& H.-J. Rheinberger (eds), Heredity Produced at the Crossroads of Biology, Politics, and Culture, 1500-1870 (Cambridge, MA, MIT Press), 133-54.

Winthrop, J. (1973), 'Familial Politics: Thomas Paine and the Killing of the King, 1776', Journal of American History, 60: 294-308. https://doi.org/10.2307/2936777

Withington, C. (1885), Consanguineous Marriages: Their Effect upon Offspring (Boston, no publisher). https://doi.org/10.1056/NEJM188508201130802

Wright C. W. (1889), A Report on Marriage and Divorce in the United States, 1867-1886 (Washington, DC, Government Printing Office).

Wyatt-Brown, B. (1982), Southern Honor: Ethics and Behavior in the Old South (Oxford, Oxford University Press).

Yazawa, M. (1985), From Colonies to Commonwealth: Familial Ideology and the Beginnings of the American Republic (Baltimore, MD, Johns Hopkins University Press).

Note on the author: Susan McKinnon is Professor Emeritus in the Department of Anthropology, University of Virginia. Her research has focussed on kinship, marriage, and gender as these relate to the structures and dynamics of hierarchy and equality as well as to the history of science and medicine. Her books include From a Shattered Sun: Hierarchy, Gender, and Alliance in the Tanimbar Islands (University of Wisconsin Press, 1991) and Neo-liberal Genetics: The Myths and Moral Tales of Evolutionary 
Psychology (Prickly Paradigm Press, 2005) as well as the co-edited volumes, Relative Values: Reconfiguring Kinship Studies (with Susan Franklin, Duke University Press, 2002), Complexities: Beyond Nature and Nurture (with Sydel Silverman, University of Chicago Press, 2005), and Vital Relations: Modernity and the Persistent Life of Kinship (with Fenella Cannell, School for Advanced Research Press, 2013). She is currently working on a book about the cultural logic of cousin marriage and its prohibition in the United States.

sm@virginia.edu

To cite the article: Susan McKinnon (2019), 'Cousin marriage, hierarchy, and heredity: contestations over domestic and national body politics in 19th-century America', Journal of the British Academy, 7: 61-88.

DOI https://doi.org/10.5871/jba/007.061

This article is licensed under a

Creative Commons Attribution-NonCommercial-NoDerivatives 4.0 International License.

Journal of the British Academy (ISSN 2052-7217) is published by

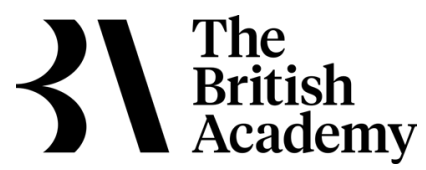

10-11 Carlton House Terrace, London, SW1Y 5AH

www.thebritishacademy.ac.uk 